\title{
The Humanitarian Regime of Sovereignty: INGOs and Iraqi Migration to Syria
}

\author{
Sophia Hoffmann
}

\begin{abstract}
This article considers the activities of international, humanitarian NGOs in Syria focused on Iraqi migrants. The analysis questions how these INGOs were positioned towards modern state sovereignty, and sovereignty's particular constructions of territory, population, and government. Arguing that most INGOs operated firmly within the social relations stipulated by modern sovereignty, the article uses rich ethnographic data to demonstrate how INGO activities treated Iraqis according to sovereign exclusions and ideas about citizenship, even though Iraqi life in Syria visibly contradicted these ideas. Only smaller, amateur INGOs that stood outside of the professional humanitarian sector were found to work outside of sovereignty's norms.
\end{abstract}

\section{Résumé}

Cet article se penche sur l'activité des organismes internationaux non gouvernementaux humanitaires auprès des migrants irakiens présents en Syrie. On y analyse comment se positionnent ces ONGI quant au discours et aux politiques de l'état moderne, et en particulier en rapport avec ses conceptions relatives à la construction du territoire, $\dot{a}$ la population et au gouvernement. On y soutient que dans la majorité des cas, les ONGI travaillent pleinement dans le cadre de la structure sociale obéissant à ces conceptions renforcées par l'état souverain, incluant des conceptions d'exclusion et de citoyenneté. Les riches données ethnographiques étudiées permettent à l'auteur de montrer comment les activités des ONGI ont conséquemment traité les irakiens selon ces représentations d'exclusion et de citoyenneté, même si la vie irakienne en Syrie les contredisait en pratique. Seules les OGNI plus petites, moins expérimentées et actives hors du réseau humanitaire professionnel semblent avoir travaillé en-dehors de ces conceptions.

$\mathrm{D}$ espite their variety, all humanitarian, international non-governmental organizations (INGOs) need to position themselves towards state sovereignty, in their management of the limits and opportunities that sovereign exclusions and boundaries pose for their operations. This article demonstrates how a small number of very different INGOs, all involved in the management of Iraqi migrants in Damascus, embedded themselves in the particular relationships of bureaucracy, money, emotion, and violence that, partly, constituted state sovereignty in this context. The article argues that INGOs played a small, but key, role in constructing state sovereignty vis-à-vis the potentially sovereignty-disturbing event of Iraqi migration. Field research found only small instances of "anti-sovereign" practices among NGO workers, which transcended the framework of social relations imposed by sovereignty.

This article is situated in the field of critical IR literature, which has in the past two decades attempted to apply Foucauldian methods in order to show how the lived reality of state sovereignty is created through minute practices of daily life. ${ }^{1}$ Migration, especially forced migration, has been recognized by critical IR scholars as a key area of contestation to the spatial and political organization of state sovereignty. ${ }^{2}$ Migration therefore provides an exceptionally rich field of study for daily-life practices through which migrants are managed and channelled into sovereignty-conform modes of life. The particular contribution of this article lies in the rich ethnographic detail that it provides to show how this managing and channelling of migrants is achieved 
through non-state agents, through practices of power that frequently lie in highly personalized interactions in areas of life not generally considered as the remit of state power. As this article shows, this development does not result in a diminishing of state sovereignty, but in a transformation of the modes of power and locations through which it becomes the hegemonic way of ordering society. As this article also shows, the diffusion of agents and loci of power that enable state sovereignty in fact make it harder to oppose, than when all or most power emanates from state institutions. Syria, where the liberal forms of power exercised by international NGOs were new, as the state had for decades used more visible techniques of violence and insecurity to rule, was a particularly interesting setting to study such transformations.

The notions of "sovereignty" and "sovereign power" are complicated by the overlapping ways in which they are deployed in a variety of social science literature to describe different concepts. In this article, "state sovereignty" describes the social, spatial, and political organization that is created by, and creates, the international system of sovereign states, as well as the domestic sovereign order of individual states. This organization rests on the one hand on the hegemonic belief that a unity of territory, government, and population-each bound to each other through politics of representation-is the natural and correct way for human life to be ordered on a global scale. This hegemonic belief is referred to in this article as the "sovereign ideal." On the other hand, state sovereignty rests on an enormous range of behaviour-practices - that transmits the sovereign ideal into the lived reality of daily life. This article mobilizes detailed ethnographic findings to show how exactly such practices, that turned hegemonic ideas about state sovereignty into lived power relations, worked in the interactions between Iraqi migrants, the Syrian state, and international NGOs. Governments-and, as this article will show, also a range of other actors - rely on a variety of techniques of power to instruct and coerce human beings into behaviour that accords with the demands of state sovereignty. What Foucauldians refer to as "sovereign power," i.e. the violent, spectacular punishment of digressions against the ruler, is one such technique. To avoid confusion, this article does not use the phrase "sovereign power" in this way. In this article, "sovereign" refers to the idea that the state should be the exclusive arbiter of life on its territory and over its population.

The final, sovereignty-related point of importance to clarify in the context of this article is the dynamic interaction between international and domestic space. While domestic space encompasses actual, geographical locations, the "international" is necessarily imagined and conceptual. The international is a purely imaginative construct that is acted out through particular behaviour and performances in geographical locations that necessarily belong to the domestic sphere of some state. Interestingly, as the clashes between the way that international NGOs constructed Iraqi migrants and the way these were integrated by the Syrian government made clear, while the practices that construct the "international" are closely related to the idealized version of state sovereignty as the territory-government-population triptych, the practices that enforce domestic sovereign orders are much more varied and context-dependent. This means that while acting as members of the "international community," NGO workers or state officials behave according to the notions of the "sovereign ideal," as if the idealized social relations of unified territory, governance, and population were a universal, lived reality. Yet when acting as members of a specific domestic order, people adjust to the particular techniques of power that are prevalent under different governments: the manner of rule in Germany is very different than that in Syria.

Professional INGOs were prevented by the Syrian government from amassing knowledge about the Iraqi population and could not conduct the "needs-assessments" that usually form the basis of aid projects. INGOs in Damascus thus based their interventions largely on assumptions about the Iraqi population, which flowed from established ideas and tropes about refugees, intimately connected to sovereignty and sovereign exclusions. ${ }^{3}$ In this way INGO practices revealed how the "sovereign ideal" of territory, nation, and government informed techniques of migration management, which in turn reproduced this ideal.

The results from field research lead to the conclusions that INGO activity transformed such social developments that destabilized sovereignty (in this case Iraqi migration) into sovereignty-conform situations. INGOs operated within the territorial and population divisions of sovereignty and maintained them. While in general INGO activity may weaken the stability and power of particular governments and may have a transformative effect on the micro-relations through which sovereignty is constructed, there appears to be no indication that, especially in the humanitarian field, INGOs weaken the ideal of sovereignty and the forms of power that flow from it. ${ }^{4}$

Empirically, this article is based on direct observations of INGO activities in Damascus, as well as "indirect" observations obtained through conversations and interviews with Iraqi migrants, foreign and Syrian INGO staff, and foreign UN staff. INGO documentation about activities for Iraqis in Syria, such as websites, funding proposals, and annual reports, was widely consulted and analyzed, to understand how the ideas and attitudes expressed in these documents related to INGO practices. 
This article is divided into four main parts. The first section will give an overview of INGO activity focused on Iraqi refugees in Damascus. The second section analyzes the practices of professional INGOs that were officially registered with the Syrian state and characterized by the ideas and language of professional humanitarianism. The third section concentrates on unofficial, semi-professional, or amateur INGOs that ran projects for Iraqis. Displaying a greater variety of approaches, these organizations' positions towards sovereignty was eclectic; sometimes confirming, sometimes undermining sovereignty. The article closes with a conclusion aiming to summarize the most important elements of the analysis.

\section{Another Consequence of the Invasion of Iraq: INGOs in Damascus}

The link between post-2003 Iraqi migration to Syria and the sudden and unexpected expansion of INGO presence in Damascus has been noted repeatedly. ${ }^{5}$ This expansion, made possible chiefly through the construction of Iraqi migration as a humanitarian catastrophe and the lobbying efforts of international advocacy organizations, was also linked to political developments in Syria, such as a growing openness among prominent government figures towards foreign NGOs and their role in economic development. ${ }^{6}$ The rapid and large-scale funding provided by North Atlantic states to UNHCR Syria for its Iraqi program, and UNHCR's need to find implementing partners to run projects, increased the pressure on the Syrian government to allow the registration of INGOs. ${ }^{7}$ Consequently, by $2009-$ 10, 13 INGOs were established as partners to UNHCR in Damascus; and around half a dozen church organizations (with international links) and a small number of private or less official international organizations operated independently. ${ }^{8}$ No public register for organizations working with Iraqi migrants existed, and despite increasingly streamlined, bureaucratic registration processes, (I)NGOs still maintained various channels with the state to authorize their activities. ${ }^{9}$ My research collected information on 10 very different INGOs, to varying extent. On two occasions, I was able to conduct repeated and intensive participant observations; on four occasions, in-depth interviews plus limited observations; at other times information was collected through informal conversations and/or interviews with INGO staff, beneficiaries, or third parties.

INGO projects ranged from professionalized services delivered by experienced, large organizations, to semi-private projects run by amateurs. Apart from the divergence among INGOs in terms of programs, staff, and set-up, a common thread was that their operations established Iraqis as recipients of either goods or services. The stated reasons for the delivery of goods/services was that Iraqis needed assistance and help to survive, and to lead meaningful and healthy lives, as reported by the numerous INGO reports on the needs and sufferings of the Iraqi community in Syria. ${ }^{10}$ This "needs-based" view of Iraqi life was also the standard argument with which INGOs justified funding requests, and was the general perspective that at least the professional INGOs used in their aid projects worldwide. In Damascus, professional INGOs generally maintained a centrally located head office, but conducted their operations in Iraqi-populated suburbs, such as Saida Zainab, Jaramana, or Yarmouk, more rarely also in cities outside Damascus such as Homs and Aleppo. Smaller, less formal INGOs were run from private flats, church facilities, or with no central location. The range of programs broadly covered medical help, education, leisure activities, and the building of infrastructure (new schools or hospital facilities). ${ }^{11}$

Accessing INGOs in Damascus proved difficult during field research. Other than I had expected, the sudden enlargement of the INGO sector had not led to increased ease of communication and transparency. Instead, many INGO employees, especially those of large organizations with little experience in Syria, were too worried about state surveillance to meet me, despite the very general and relatively non-controversial focus of my research. While initially frustrating, these experiences became valuable information in their own right, as they expressed ways of control and self-preservation exercised by INGO employees, and related to questions about Syrian state sovereignty.

\section{Professional Humanitarian INGOs}

Professional INGOs were those organizations that already had a large portfolio of aid projects in Asia and Africa, and for which Syria simply represented the entry into a new "market," where previous experiences could be adapted and rolled out. For these organizations, which formed part of the global, professional humanitarian sector, entry into Syria was simply an expansion of their existing programs elsewhere. As will be argued and demonstrated, their practices, beliefs, and set-ups intimately connected them to the political, social, and spatial organization of the sovereign ideal of a unity of territory, government, and population, as well as the idea that the government-citizen relationship is one of mutual rights and duties, and protection. Such organizations included Danish Refugee Council, Terres des Hommes, the International Rescue Committee (IRC), and Première Urgence, established bureaucratic apparatuses and players in the global humanitarian sector. ${ }^{12}$ Their modus operandi included standardized regulatory requirements, including a degree of transparency, financial accountability, 
and bureaucratic continuity, which significantly influenced their interactions with the Syrian state. ${ }^{13}$

One of the few professional INGOs that responded to my requests for an interview was the IRC, one of two US-based INGOs operating in Damascus. ${ }^{14}$ The interview took place at IRC's inconspicuous office behind a main road in central Damascus, located in a typical, French-style Damascus flat on the first floor, with wide stone floors and high windows. Three employees, two Syrian, one European, provided me with an overview of the organization's activities with Iraqi refugees, which at that time consisted of projects in the education sector. IRC was renovating and improving a number of schools in deprived suburbs and offering remedial classes for Iraqi pupils. ${ }^{15}$

Three main ideas emerged from the interview: firstly, that Iraqi pupils faced problems when trying to attend school in Syria and in turn created problems for the education sector; secondly, that Syria was a new and difficult context for IRC to operate in due to the control exercised by state institutions; and thirdly, that funding constraints and opportunities were a central concern for IRC. The expatriate director conveyed a businesslike attitude, focused on the managerial challenges faced by IRC such as the obtaining of funds, the hiring of staff, and compliance with government regulations.

\section{A Deviant Population}

One of the Syrian staff explained that there were around 1.5 million Iraqi refugees in Syria and that 60 percent of Iraqi children did not attend school, adding:

As you might have read, Syrian schools suffered from overcrowding. First, the Iraqis face many challenges when it comes to schooling. For example, with the English language, in Syria we start in year one, whereas in Iraq they only start in year seven, so there is a very big gap there. Then there are the financial problems, this is probably the biggest problem. Often children have to work and families live off their wages. ${ }^{16}$

This rhetoric closely reflected the language and information about Iraqis on IRC's website and the organization's press releases and reports. ${ }^{17}$ Iraqis in Syria were presented as hopelessly troubled and in desperate need of the world's attention and aid. IRC's language was, even compared to that of other NGOs, extreme in this regard; however, it nevertheless represented broadly the tone of most INGO publications on Iraqi refugees, as illustrated by the selection of texts below.

The Danish Refugee Council's website depicted Iraqi life as follows (similar wording in the organization's quarterly reports):
Humanitarian needs

Due to their illegal status, the Iraqi refugee population in Syria is facing a difficult situation being both illegal and out of funds, and their possibilities of living a decent life are limited. The influx of refugees has created additional inflation and pressure on the job market in the country. Criminality has increased, and prostitution of young Iraqi women in need of cash support has become a reason for resentment by the host community. The Syrian education system is also struggling to cope with the increased numbers of children and the access to secondary or tertiary health care systems for Iraqis with chronic diseases is very limited. ${ }^{18}$

The website of Terres des Hommes Switzerland, which supports a number of health-projects in Syria, carries the following description:

\section{Regional assistance to Iraqi refugees}

The Iraqi groups who have taken up temporary refuge in Syria and Jordan are in great distress. They have very few rights and no access to adequate services, in particular in the field of psychology. However, this is where their needs are greatest because of the trauma experienced during the war, while fleeing and also during their stay in the country which has taken them in. TdH is providing psychological and social help to these children and their families in Jordan, where it has opened a centre. Two partner relief organizations are working in Syria. ${ }^{19}$

These images of Iraqi migrants, which are focused exclusively on the negative elements of their life and migration experience, cast the population as problematic and in need of correction. The notable focus on psychological trauma and sexual deviance (an often repeated trope in INGO publications on Iraqi refugees) located Iraqis' problems firmly inside their own minds and bodies, implying and highlighting the need for interventions targeting Iraqi lives and individuals, rather than the external, political circumstances that were contributing to Iraqi poverty. Unsurprisingly, this was indeed the form that many professional INGO projects took.

Crucially, the connection between Iraqis' problems and the fact that they were migrants/refugees was made throughout these texts. Emphasis was placed on the assumed illegality of Iraqis in their states of exile and their lack of rights. The act of migration to another state, and the existence as a refugee, was portrayed as an existence of last resort, an unnatural existence, as it placed Iraqis outside of the sovereign norm, according to which humans must reside on the territory of a government offering them a legally binding relationship of rights (which the Syrian government, which operated a policy of renewable, temporary residency permits in addition to tolerating transgressions against work 
prohibitions and outdated permits, did not). ${ }^{20}$ Crucial to the argument of this article were the implicit and explicit constructions of state sovereignty as the accepted, correct, and existing political organization that emerged from these statements, and the assumed impossibility of a good life outside the home state. These constructions implied that a clear, legal connection to a protective sovereign state were a fundamental requirement for leading a secure and stable existence. The act of crossing state borders was understood as outside the norm and only to be taken in extreme circumstance, with severe consequences such as illegality and the need for outside help. Iraqi existence outside of Iraq's territory was not taken as an indication of the lack of truth of the stipulated, sovereign unity of government, territory, and population, but as a wrong, bad, and dangerous state of affairs that needed to be corrected so that the (fictional) correct, good, and safe situation of sovereignty could be regained.

INGO rhetoric and practice was here firmly within the discourse of the modern ideal of sovereignty and neither weakened nor deconstructed it. Descriptions of Iraqi activities in exile that contradicted the sovereign ideal, and that placed into question the notions of sovereign legality, citizenship, and nationality, were absent from INGO rhetoric and, broadly, from their programs-even though such activities were highly visible in Damascene suburbs at the time. Despite the troubled situation in their society of origin and their often horrible recent past, Iraqis in Damascus were also thriving: through their own strength and due to a political, social, and cultural context that did not produce them as hopeless, non-sovereign outsiders. But in INGO texts, the natural and ideally best location for Iraqis was the territory of Iraq and the sovereign space of the Iraqi state, and it was only highly exceptional circumstances that had undone this natural and baseline situation. Through this selective portrayal of Iraqi existence in Syria, INGOs strengthened the construction of the sovereign ideal in a context where the lived reality of Iraqis in Syria placed it in question.

\section{State-NGO Relations}

Returning to the IRC interview, the second important point concerning professional INGOs and sovereignty that emerged was the interaction between IRC and Syrian state institutions. When I asked whether I could visit one of their projects, IRC's expatriate director warned me:

This is not a regular environment for NGOs, I will request approval and I'm sure that there will not be a problem but we will have to see. In a different context we would take you along and show you everything, but here ... ${ }^{21}$
The IRC interlocutors explained that their actions were closely monitored by officials from the Ministry of Education, with whom they met every week to discuss progress and to request approvals. After broad approval had been received, further requests had to be made regularly even for small activities, such as distributing leaflets to inform Iraqi students about projects.

The schools that IRC was rebuilding and renovating, located in the suburbs Harasta, Qudseya, and Bila, had been chosen by the Ministry of Education, rather than by an independent needs assessment. Concerning the information and statistics about Iraqi pupils, according to which the schools had been identified (Syrian government statistics are notoriously poor and/or non-existent), the IRC staff explained that it was not easy to get information, as the statistics of the ministry were old, and that IRC used a mixture of government and UNHCR statistics for their purposes. The knowledge and figures about Iraqis, which IRC staff so confidently provided, thus appeared largely as assumptions, rather than empirically researched. In this particular case, IRC's choices and projects were so closely related to those of the ministry that the boundary between governmental and non-governmental appeared blurred.

The close monitoring and control exercised by Syrian ministries over INGO activities and knowledge was further described in an insightful report by the Middle East Institute, as illustrated by the following extract, describing INGO registration procedures: ${ }^{22}$

\footnotetext{
One condition to be accredited is to present proof that the organization is fully funded. The second step is to submit a project proposal to SARC without being able to a conduct preliminary needs assessment. After SARC approves the proposal, it signs a Memorandum of Understanding (MoU) with the INGO. The MoU was particularly challenging for the first INGOs that signed agreements with SARC: these agreements included the obligation for INGOs to share a common bank account with SARC, and the need for SARC's approval for any disbursement or the payment of 2 percent of the NGOs' budget to SARC in compensation for expenses related to the partnership. A few months later, these financial arrangements were lifted after SARC realized that they were time consuming, impractical, and unacceptable by donors and INGOs $[s i c] .{ }^{23}$
}

The described restrictions partly explained the reluctance of INGO representatives to meet with me as a researcher. More importantly, the quote demonstrates that professional INGOs transported norms, ideas, and behaviours onto Syrian territory, which were different to those expected by state officials. Further, the highlighted tensions show how clashes and squabbles over the "way to do things" could lead 
to changes in practices and beliefs on both sides, resulting in new micro-practices that could gradually produce social and political transformations to the way the Syrian government was able to enforce the Syrian state's sovereignty over its territory and the people residing on it.

The importance of the tense relationship between professional INGOs and Syrian state institutions for analysis of sovereignty concerned both the domestic and international sovereignty of the Syrian state. Domestically, INGO programs and procedures changed, on a minuscule level, the way state institutions intervened in private lives in Syria introducing new forms of power into the sphere of Syrian domestic sovereignty. INGO projects developed new public spaces, which remained heavily state controlled, through the operation of community centres or women's shelters, and ran unprecedented programs focused on the inner life of individuals, such as psychosocial counselling or parenting skills. These new forms of social organization and interventions included new governance techniques, in which the Syrian state appeared in various, and new, forms. For example, the existence of foreign and Syrian INGO staff, and spaces associated with INGOs, created new opportun ities for state officials to demonstrate the state's presence in these newly created domestic spheres. Again, INGO activities thus did not weaken the sovereignty of the Syrian state over Syrian territory; however, they changed the way this sovereignty could be performed and experienced.

Professional INGO programs also introduced a strict conceptual distinction between Iraqi and Syrian "beneficiaries," as their project proposals and reports stipulated percentages for both. This practice made the national division, a key organizing principle of modern sovereignty, visible and fixed to all involved in the programs and elevated it to new importance. ${ }^{24}$ Particularly in the field of education projects, the continued distinction made between Syrian and Iraqi children, the latter described as the reason for the overcrowding of schools, was striking. To use the example of Première Urgence's description of its school rehabilitation program, in an announcement concerning the completion of two new school buildings:

These two schools, with a capacity to host 1.050 pupils, will allow the development of a response to the overcrowding of Syrian public schools and will promote the enrolment of Iraqi refugee children. Over 33.500 Iraqi children are enrolled in Syrian schools and over $75 \%$ of these are attending schools in the greater Damascus region. ( ... )

"We are proud of this result and are now eagerly looking forward to the creation of educational programmes with the support of the Syrian ministry for education, with the goal to ensure the future of Syrian and Iraqi children" explained Sandar Bachrach, Première Urgence's chief of mission in Syria.

In this text, Première Urgence is not simply concerned with easing the lives of disadvantaged youngsters, but is also focused on promoting a distinction between Iraqi and Syrian children. The reference to overcrowding and the figures, percentages, and locations of Iraqi children imply that Iraqi children are somehow alien to the Syrian education sector. Given that the raison d'être of INGOs' presence in Syria was the existence of "alien," Iraqi refugees, promoting their distinction was in fact existential to these organizations. This observation again points out that INGOs working on refugee issues were closely bound to the exclusions of sovereignty, rather than standing outside or even opposed to such exclusions. In the Syrian context, what made these INGO practices all the more striking were how they differed from the opportunities for integration that were offered by the Syrian government's policies towards Iraqis. The ease with which Iraqi children could register with and attend Syrian schools stood in stark contradictions to the portrayal of these children by INGO texts and programs. The Syrian government did not mobilize elements of the state (in this case the education system) to systematically exclude Iraqis and in this way demonstrate the unity and homogeneity of the Syrian national population. Such exclusions were not an integral part of the repertoire of power through which the Syrian government emphasized the state's sovereignty. Instead, this sovereignty was created through practices of insecurity and violence that applied to everyone residing on Syrian territory, be they Syrian or foreign passport holders. These contradictions demonstrated how humanitarian approaches to population management can transform the way governments view and act upon migration and can introduce different, more subtle forms of power through which the order of state sovereignty is created and maintained. Yet the Syrian situation, in which INGOs also had to adapt to requirements by the Syrian government, also highlighted that such changes occurred through dynamic exchange, in which both sides influenced each other's room to operate.

\section{Semi-official and Unofficial INGOs}

In addition to the large, professional INGOs described above, in 2009-10 a number of organizations operated aid projects for Iraqis in Damascus that were neither officially registered with the Syrian government nor reliant on professional staff. These organizations did not maintain regular, close contact with Syrian ministries; their staff possessed a deeper, more intuitive knowledge of Syrian government red lines, and were open to meeting me as a researcher and 
allowing me to participate in and observe their programs. All organizations maintained a very low profile.

\section{Iraqi Student Project}

The "semi-official" INGO that I had closest access to, and which was the most intriguing of all, was an organization called Iraqi Student Project (ISP). This organization had been set up by a retired couple from the US, to help gifted Iraqi high school graduates receive scholarships to liberal arts colleges in the US. Apart from a single paid employee in the US, where ISP was registered as a non-profit organization, this INGO was funded entirely through the couple's income from social security and donations of time and money from a small group of supporters in the US and Syria. ${ }^{25}$ The organization was run out of the couple's rented, two-bedroom flat in central Damascus, which functioned as a live/ work space, where volunteer teachers-often American or British TOEFL teachers working at the American Language Institute close by-ran classes to prepare the selected students for their study and life in the US. ${ }^{26}$

The central fascination that developed from the participant-observation at ISP concerned the intense and complicated power dynamics between the elderly directors, the volunteers, and the young Iraqi students. After several severe conflicts at the organization, in which students were expelled from the program for unclear reasons, I became aware of how the power imbalance between directors and students worked underneath the egalitarian and peaceful veneer. Given this article's focus on the construction of sovereignty through INGO programs, the following paragraphs aim to tease out how ideas and practices of sovereignty were present in the relationships at ISP.

The selection process for students was based on several standard items, such as being Iraqi, not having been accepted for UNHCR resettlement, having a good school record, and expressing an interest to return to Iraq after finishing college to contribute to the country's future. In addition, selection depended on assessments of the candidate's family environment, his/her psychological stability, and potential for coping alone in a foreign country. These assessments were carried out in a relatively informal manner by the two directors, through home visits and interviews. If selected, candidates joined a program of classes and were subjected to continuing, broadly informal monitoring by the directors and volunteer teachers. Should a student become considered as "not ready," she or he could be required to complete a further year of program, or could be expelled at any time.

The personal nature of these assessments is illustrated by the field note excerpt below, reporting a conversation with one of the directors about several of the students (all names have been changed):

He talked about Ibrahim and how he was such a great kid. "This guy's essays, they are just so good, his use of English. ... If I could speak directly to any of the people in admission at the colleges, I would really tell him to take this guy, he's just going to take off and flourish over there." It's clear that Ibrahim is one of the director's favourites and I just can't get it out of my head that it has to do with his pretty tough story of 1.5 years in poverty in Jordan, during which he was alone with his father and had to take care of the household etc. ( ... )

He named Radi as one of the students that he had some doubts about having the maturity to success "once he is alone over there". While he acknowledged that Radi was very passionate about his subject and very good in class in getting the others to participate, he somehow doubted that Radi had the toughness to "hack it" once out there in the states by himself. I was quite surprised by this assessment, as Radi lives on his own in Syria and is managing his affairs by himself, and while there is indeed something quite "young" about him, I personally definitely found him quite tough and grounded. ${ }^{27}$

The two directors' personal view of students held enormous sway over their future, as most students considered their success in the program as monumentally important. One Iraqi young woman described how, at the time that she was being considered for ISP, her alternative option would have been a job as a waitress in one of the new malls of Damascus, highlighting how the chance to complete a university degree in the US was an extremely desirable exit from a dead-end existence in Syria. This desire to succeed, coupled with the arbitrary and personal control exercised by the program directors, created pressure to conform. The following extract from a conversation with one of the Iraqi students, which occurred in the immediate aftermath of the sudden and unexpected dismissal of another student, highlights this situation.

The thing with Hussein was such a shock. With Huda, ok, it was kind of predictable that they wanted to kick her out, but with Hassan it was a complete shock. Everyone likes him, he is such a friendly and smart guy. And they did not give him a warning. After this, everyone feels insecure, no one knows what is going to happen. ( ... )

I feel so afraid now. Do we have to depend on her moods? Everything can change, I don't know how to behave so that she likes me. Today when she said something about my trousers, I thought oh no, I'm not going to wear these trousers again. Does 
she not like my hair the way it is? Does she not like my nose today? Or if I write an essay that she does not like ... First we were under pressure in Iraq, then we were under the pressure of the Syrian government, when we don't know whether they will kick the Iraqis out and now we are under the pressure of ISP. ${ }^{28}$

This statement crystallizes how personal relationships at the program were fused with wider, political relationships of sovereignty that strongly influenced the power dynamics at work. The nature of the relationships at ISP could only be explained with reference to the material and imagined realities of sovereignty, indeed they were sovereignty in the sense that they replicated and confirmed the particular divisions of territory, population, and government that lie at sovereignty's heart. Materially, the power exercised by the ISP directors was directly linked to their US citizenship which, in accordance with sovereignty, bonded them to the US government, which provided them with the money required to run their organization. Their security and power was inversely reflected by the insecurity and weakness of the Iraqi students, whose Iraqi citizenship bonded them to the Iraqi government, which provided them with neither opportunities nor money. In this way, the ISP program reinforced and magnified the sovereign ideal in an environment in which Iraqi migration in fact often blurred it.

The constructions of sovereignty on the level of imagination and ideas that emerged at ISP were much harder to pin down, and full of contradictions. Students were frequently encouraged to express their national pride as Iraqis, and numerous books about Iraq's rich history and maps were displayed in the ISP flat. But representations of Iraq as a place of destruction and hopelessness also abounded, in which the US appeared as a safe haven, the only chance for these students to lead meaningful lives. The ISP directors were frequently cynical and critical about US politics in the Middle East, but strongly celebrated other instances of US culture, such as the 1960s peace movement (which they remembered fondly) and the civil rights campaigns, and encouraged the students to celebrate these too. Students were also encouraged to abandon certain cultural traits, and there was a narrow framework of behaviour that made someone a "good ISP kid." The following extracts from conversations with the ISP directors develop some of the complex understandings of the US and Iraq as separate spaces that were present throughout the ISP programs:

The students get taught for one year by voluntary teachers to improve their English and to prepare them for the way teaching is done in the US. In Iraq, students generally learn information off by heart and reproduce it in the text. In the US, they have to learn critical thinking and analysis and to write good essays. There are classes every day. Once a week my wife [one of the directors] does a writer's workshop which focuses on essay writing skills. [ ... ]

For many Americans it is an experience to meet an Iraqi. It becomes a real place for them. One of our students was at immigration, when the officer stopped short at the passport and did a double take, then expressed surprise that this girl, who does not wear the hijab and wears modern clothes, could be from Iraq. "You can walk around like that in Iraq?" Yes you can. "Is that a tattoo?" Yes. "You can have a tattoo in Iraq?" Yes you can..$^{29}$

Iraq and the US emerged as two distinct educational spaces, in which knowledge and knowledge-production functioned, were understood, and were valued differently. In order to succeed in the US, the students had to abandon aspects of their previous, "Iraqi" learning and acquire new modes of knowledge and thinking. Modern state sovereignty closely links knowledge-production to questions of legitimacy and government. Distinct epistemologies connect citizens to the imagined sovereign in a particular way and establish the citizen's home-state as different (and often better) than all other states; the fundamental boundaries of security and global hierarchy are established through discourses about what constitutes valuable, useful, dynamic and creative learning and knowledge, as much as through other media. ${ }^{30}$ In this sense, knowledge and education have replaced, or have been added to, oaths of allegiance and/ or religion as ways of connecting populations with their rulers. $^{31}$

Such distinct forms of knowledge became visible at ISP seminars, during discussions about representations of Iraq and the schooling the students had experienced in the past. The recordings of a number of classes showed that, of course, Iraqis did indeed learn a form of "critical thinking" in Iraqi schools; however its form and content would probably be dismissed as uncritical and simplistic anti-Western propaganda by most "Western" observers. Most of the students reflected critically themselves on the image of a rapacious and imperialist US waiting to steal Iraq's oil they had been taught. ${ }^{32}$ Crucially, these observations demonstrated that knowledge and its content were linked to territory and government, and were forms of power controlled by state institutions, through which the state's sovereignty and the unity of its government, population, and territory were created and demonstrated. To "fit in" and succeed at US colleges, Iraqi students had to acquire the modes of knowledge production intimately tied to US sovereignty, that indicated US territory as a separate physical and conceptual space. It was remarkable that the ISP directors considered it necessary that the students at ISP (who had already been preselected according to criteria of education and personality that made 
them conform more with US college life) received months of training to achieve an appropriate standard; their experience of several students failing in the US had taught them that students needed much more than English language training to "make it."

\section{Native without a Nation}

In a different way, education also played a central role for the activities of the small, informal INGO Native without a Nation (NWN), created and run principally by an Iraqi man called Firas. NWN's activities, which consisted of IT-skills and creative workshops for children and teenagers, home visits to depressed and/or hard-up families, and Skype exchanges between Iraqi and US youngsters, had developed out of Firas's personal social activism since his arrival in Syria in 2006. Further, NWN ran a website, on which Iraqi teenagers could publish their stories and art work. ${ }^{33} \mathrm{~A}$ small group of US-based supporters helped organize the Internet exchanges with a school in upstate New York, US; funding was restricted to occasional donations of equipment from friends and small cash donations. ${ }^{34}$ Although NWN's projects helped Iraqis, thus making a distinction based on national identity, the organization's close focus on personal narratives, friendship, and non-judgmental compassion made it an example of international solidarity that did not depend on reconstructions of the sovereign ideal or the categorization of people into sovereign types.

Although (or because) Firas, who had in-depth personal experience of UNHCR's application of sovereignty, and that of the Syrian state, was heavily affected by all manner of sovereign regulations, NWN's "humanitarian" activities emphasized personal expressions of the persons involved in the projects. There was little or no indication that broad assumptions were drawn about people's "needs" or deviations due to the categories, values, and exclusions of sovereignty. NWN's website presented the stories of some participants without judgment-laden introductions or texts about the situation of Iraqis as such, their illegality, and so forth. ${ }^{35}$ Many narratives concerned memories of violence experienced in Baghdad, but many also articulated instances of empowerment and independence. One of Firas's stated aims was to develop a platform for young Iraqi people to express themselves in their own words and thoughts. The following quotes from the website illustrate their diversity and the aim of self-expression:

\section{Othman Abd Al-Rahman Mohammad}

My name is Othman Abd Al-Rahman Mohammad. I am an Iraq pupil and I am proud of being an Iraqi. Despite the fact that I live in my second country Syria, I love this country so much as well as its generous people.
I love to study in a perfect way. I love my school, my family and my relatives who are away from me due to the cruel circumstances. I also love helping my father with the housework.

From Noor, Muna and Anfal

Since the first art show we had in Damascus, we felt admiration and encouragement from the audience to continue painting, and talk about the mixtures of colors. We were often asked if we ever went to art schools. The answer always is "We never studied art, it's just what we do and like to do. We do express what we feel and we convert it on our paintings." ( ... ) At the end of the meeting we agreed that we have to be strong and keep getting better. We noticed the difference between the first and last art show, our paintings became stronger and more expressive through the subjects and the colors. Every painting had story. Now we are preparing for another art show, with new paintings, new stories, and new style.

We will never stop looking forward. We will never be silent.
Mustafa, 17
(...)
I will never forget that accident. I no more want to be in Iraq so that I don't have to face any of this again. That doesn't make my situation any easier as I have heart failure and the medical care is basically non-existent. All I hope for is to know my future after registering with the UNHCR as a refugee. ${ }^{36}$

Sovereignty's divisions are not absent from these selfrepresentations, and sovereign boundaries, both physical and imagined, structure the thoughts and practices of these young people. However the key point concerning NWN's activities was that they did not reproduce or use sovereignty as a reference point in the same way as other INGOs; they did not contain regulations or classifications according to people's position vis-à-vis an assumed, protective sovereign. NWN did not run programs that were predesigned according to ideas about refugees based on the sovereign ideal. NWN's semi-spontaneous interventions relied on indepth personal knowledge of persons who were interested in support. Rather than aiming to guide or change these lives in any particular direction, this support created small instances of success or positive feelings, which empowered people to continue struggling against the often overwhelming way in which sovereignty's exclusions were affecting them. By ignoring sovereignty's framework in these small ways, NWN's practices used an alternative lens through which Iraqis in Syria were not consistently recast as outside sovereignty, but simply as fellow humans who had fallen on hard times. 
A similar dynamic could be observed during the web conferences that NWN organized between Iraqi youth in Damascus and a school class in upstate New York, US. These conferences, held about every six months, were conducted via the Internet-telephony program Skype, and included video-calling, so that the partaking individuals could see each other. During the calls, the children and teenagers would introduce themselves and show each other art work they had made, or narrate items they had recently studied. The focus on shared, enjoyable activities among individuals (rather than divisive, negative experiences of imagined collectives) created a basis of understanding of one another's humanness, regardless of sovereignty's territorial, governmental, and population divisions. The empowering aspect of the Internet's territory-undermining technology, which can create non-territorial communities and nations, was a crucial aspect for this project.

\section{Conclusion}

Research conducted among INGOs in Damascus in 200910 found that most INGO activities were based on and promoted modern state sovereignty as the normal, safe, and correct form of political organization. Iraqis in Syria, who were the raison d'être for INGOs' presence in Syria in the first place, were continuously depicted and treated as alien, illegal, and helpless, due to their location outside of the territory that their nationality allocated to them. Rather than considering Iraqi life in Syria as an indication for the fiction and weakness of the assumed unity of population, territory, and government, INGO activities consistently portrayed it as an instance in which this unity had been tragically broken. From this perspective, Iraqis in Syria could never be regarded as normal instances of human life, but were necessarily cast as deviant and in need of protection and correction through INGO interventions.

The rich ethnographic detail provided throughout this article demonstrated how highly personalized interactions, and social programs focused on areas of life ostensibly outside of the remit of state intervention, contributed to the maintenance of state sovereignty's political, social, and spatial organization. Unlike the frequent assumption, state sovereignty not only was upheld through power exercised by state institutions, but, in the case of international NGOS, was carried out through diffuse and non-violent techniques of power that were much harder to discern than, for example, the highly visible violence exercised by the Syrian government as a means of creating sovereignty.

Research found that INGOs conducting aid projects for Iraqis broadly fell into two separate groups. The first group consisted of around a dozen professional and officially registered organizations, such as Danish Refugee Council or International Rescue Committee. These INGOs were established members of the global, professional humanitarian sector and had standard procedures and regulations on how to set up projects, raise and organize funds, publish annual reports, recruit staff, and so on. The language and programming of these organizations were fully sovereigntyconform; this was particularly visible from the highly selective portrayal of Iraqi life in exile, from the INGOs' tense relationship with the Syrian state that revealed transformation to how sovereignty was exercised on Syrian territory, and from their dependence on funding from North Atlantic states that carried with it a narrow framework of action.

The second group of INGOs was typified by their informality, their lack of official registration with state authorities, and their reliance on volunteers rather than paid professionals. This divergent group of organizations included a semi-professional INGO with several dozens of volunteers as well as one-man outfits with little external support. Consequently, these organizations' position towards sovereignty was eclectic. One organization, focused on helping young Iraqis access US colleges, demonstrated how education and knowledge was linked to sovereignty, as Iraq and the US were understood as separated by different epistemologies and forms of learning. Here, educational practice was revealed as linking citizens to territory and government, according to rules set by the state. A second informal INGO ran projects emphasizing the commonalities among Iraqi and US youth, without reifying Iraqi life in exile according to familiar humanitarian tropes. In this way, sovereign exclusions were overcome by simple expressions of human solidarity and by a form of organization in which roles of provider and beneficiary, of leader and led, were blurred and unclear.

\section{Notes}

1. This article stands in conversation with critical and anthropological analyses of modern state sovereignty as a particular, historically evolved, organization of political life. See, for example, Richard K. Ashley and R. B. J. Walker, "Reading Dissidence/Writing the Discipline: Crisis and the Question of Sovereignty in International Studies," International Studies Quarterly 34, no. 3 (1990): 367-416; Thomas J. Biersteker and Cynthia Weber, eds., State Sovereignty as Social Construct, Cambridge Studies in International Relations, no. 46 (Cambridge and New York: Cambridge University Press, 1996); Galina Cornelisse, Immigration Detention and Human Rights Rethinking Territorial Sovereignty (Leiden and Boston: Martin Nijhoff, 2010); Ilana Feldman, Governing Gaza: Bureaucracy, Authority, and the Work of Rule, 1917-1967 (Durham: Duke University Press, 2008); Michael Foucault, Security, 
Territory, Population: Lectures at the Collège de France 1975-1976 (Basingstoke: Palgrave Macmillan, 2007); Aiwa Ong, Neoliberalism as Exception: Mutations in Citizenship and Sovereignty (Durham: Duke University Press, 2006).

2. Mark B. Salter, "The Global Visa Regime and the Political Technologies of the International Self: Borders, Bodies, Biopolitics," Alternatives: Global, Local, Political 31, no. 2 (2006): 167-89; Didier Bigo, "Security and Immigration: Toward a Critique of the Governmentality of Unease," Alternatives: Global, Local, Political 27, no. 1 suppl. (2002): 63-92; Peter Nyers, Rethinking Refugees: Beyond States of Emergency (New York and London: Routledge, 2006).

3. Emma Haddad, "The Refugee: The Individual between Sovereigns," Global Society 17, no. 3 (2003): 297-322.

4. Ole Jacob Sending and Iver B. Neumann, "Governance to Governmentality: Analyzing NGOs, States, and Power," International Studies Quarterly 50, no. 3 (2006): 651-72.

5. See for example Katherine Kraft, Two Changing Spheres: NGOs and Iraqis in Syria (Brea: Middle East Fellowship, 2008); Geraldine Chatelard, "What Visibility Conceals: ReEmbedding Refugee Migration from Iraq," in Dispossession and Displacement: Forced Migration in the Middle East and Africa, ed. Dawn Chatty (London: British Academy, 2009).

6. See for example the speech of Syria's first lady at Syria's first conference on NGOs and Development, organized under her lead. The speech is available at: http:// www.presidentassad.net/ASMA_AL_ASSAD/Asma_Al_ Assad_News_2010/Asma_Al_Assad_NGO_Conference_ Inauguration_2010.htm.

7. UNHCR Syria, "UNHCR Signs Landmark Accord in Syria with International NGO," press release, UNHCR Syria, 8 May 2008.

8. UNHCR Syria, "UNHCR Syria Update Autumn 2009”, in UNHCR Syria Updates (Damascus: UNHCR Syria, 2009).

9. Kraft, Two Changing Spheres.

10. Patricia Weiss Fagen, Iraqi Refugees: Seeking Stability in Syria and Jordan (Washington, DC: Institute for the Study of International Migration, Georgetown University, 2007); Frauke Riller, On the Resettlement Expectations of Iraqi Refugees in Lebanon, Jordan and Syria (Beirut: UNHCR / International Catholic Migration Mission, 2009); Salome Philmann and Nathalie Stiennon, 10,000 Refugees from Iraq: A Report on Joint Resettlement in the European Union (Brussels: ICMC / International Rescue Committee, May 2010); IRC Commission on Iraqi Refugees, A Tough Road Home: Uprooted Iraqis in Jordan, Syria and Iraq (New York: IRC, February 2010); Elizabeth Ferris, Going Home? Prospects and Pitfalls for Large-Scale Returns of Iraqis (Bern: Brookings-Bern Project on Internal Displacement, 2009).

11. For a good overview of the sector see OCHA, Regional Response Plan for Iraqi Refugees (New York: United Nations, 2010).

12. Terres des Hommes presents a slightly special case, as a Syrian branch of TdH Lausanne has been active in Damascus since decades, originally focusing on helping refugees from Palestine. TdH Syria/Lausanne became involved with Iraqi refugees in 2007 when UNHCR was looking for any established organizations that would be able to implement Iraqi refugee projects.

13. Enza Di Iorio and Martine Zeuthen, "The Benefits of Engaging and Building Trust with a Reluctant Government: The Experience of Community Center for Iraqis in Syria," in Iraq Study Group (Washington, DC: Refugee Cooperation / Middle East Institute, 2011).

14. Interlocutors with INGO experience in Syria reported on an existing ban on US-based INGOs stated in Syrian government documents; it remains unclear why IRC was allowed to register.

15. Interview at the IRC, 19 October 2009.

16. Ibid.

17. IRC Commission on Iraqi Refugees, A Tough Road Home Uprooted Iraqis in Jordan, Syria and Iraq (New York: IRC, February 2010); IRC Commission on Iraqi Refugees, Five Years Later, a Hidden Crisis (New York: IRC, March 2008); "IRC Press Release: International Rescue Committee Set to Begin Aid Programmes for Iraqi Refugees in Syria," IRC, 2 September 2008.

18. Danish Refugee Council, Quarterly Report (Syria) JulySeptember 2010 (Damascus: DRC, 2010); DRC Quarterly Report (Syria) October-December 2010 (Damascus: DRC, 2011).

19. See Terres des Hommes, http://www.tdh.ch/en/countries /syria-jordan.

20. I do not wish to belittle the suffering of Iraqis in Syria. The aim is to point out that INGO rhetoric reduced the extremely varied existence of Iraqis in exile, which also included successes, opportunities, strength, health, and self-help, to that of suffering and weakness, and in this contributed to the construction of sovereignty. It is also important to point out that the reasons to remain in exile, after the initial flight, were very varied, including cultural, economic, and social preferences for staying in Syria, not just fear.

21. Interview with IRC, 19 October 2009. Incidentally my follow-up emails were never answered.

22. Di Iorio and Zeuthen, The Benefits of Engaging and Building Trust with a Reluctant Government. Note: SARC refers to the Syrian Arab Red Crescent, a government controlled health organization.

23. Ibid.

24. I recall visits to a number of aid projects in 2007 run by churches, who were reporting an increase in attendance of Iraqi visitors (i.e. these were pre-existing projects aimed at all poor people). While the project attendants were certainly aware of who was an Iraqi, they emphasized their openness to anyone in need and did not keep tabs on Syrian and Iraqi visitors, due to a firm conceptual distinction of their social roles.

25. It should be noted that the couple running ISP was by no means wealthy or that they benefited from a large 
retirement. Both had worked in education and/or publishing to not highly lucrative gain.

26. See the organization's website, www.iraqistudentproject .org.

27. Field note, 16 January 2010 (all names changed).

28. Field note, 8 February 2010 (all names changed).

29. Field note, 22 October 2009 (all names changed).

30. David Campbell, Writing Security-United States Foreign Policy and the Politics of Identity (Manchester: Manchester University Press, 1992); Mark B. Salter, Barbarians and Civilization in International Relations (London: Pluto Press, 2002).

31. Michel Foucault, Mauro Bertani, and Alessandro Fontana, Society Must Be Defended: Lectures at the Collège de France, 1975-76 (London: Allen Lane, 2003).

32. This point is clearly an invitation to reflect on the forms of uncritical propaganda taught in US schools, which cannot be elaborated on here.
33. http://nativewithoutanation.blogspot.com/.

34. In 2011, the organization had collected around \$2,800 USD, according to the website.

35. And interestingly, the few tropes about Iraqis in Syria exhibited by the website, in the familiar, humanitarian language, were evidently written by the overseas supporters.

36. All texts taken from http://nativewithoutanation.blogspot .com/.

Sophia Hoffman is a teaching fellow at the Geneva Graduate Institute. She received her PhD from SOAS, University of London, in March 2012. The author wishes to thank the anonymous reviewers for their helpful comments, which resulted in useful revisions to clarify this article's arguments and position. 